\title{
Adipokines Network in Adolescent Girls with Polycystic Ovary Syndrome
}

\section{Sieć adipokin u dziewcząt z zespołem policystycznych jajników}

\author{
'Zofia Prokopowicz, ${ }^{2}$ Sasa Stupar, ${ }^{1}$ Agnieszka Zachurzok, ${ }^{1}$ Ewa Malecka-Tendera
}

\author{
${ }^{1}$ Department of Paediatrics, Paediatric Endocrinology and Diabetes, Medical University of Silesia, Katowice, Poland \\ Faculty of Medicine, University of Ljubljana, Slovenia \\ ${ }^{1}$ Klinika Pediatrii, Endokrynologii i Diabetologii, Śląski Uniwersytet Medyczny, Katowice, Polska \\ ${ }^{2}$ Wydział Medyczny Uniwersytetu w Lublanie, Słowenia
}

Corresponding author:

Zofia Prokopowicz, Department of Paediatric, Padiatric Endocrinology and Diabetes Medical University of Silesia, Medykow Street 16, 40-752 Katowice, Poland, tel.: +48 32207 16 54; fax: +48 32207 16 53, e-mail: m.z.m@interia.pl

Key words: adipokines, polycystic ovary syndrome, adolescent girls

Słowa kluczowe: adipokiny, zespół policystycznych jajników, nastoletnie dziewczęta

\section{ABSTRACT/STRESZCZENIE}

There is a complex interrelationship between polycystic ovary syndrome (PCOS) and excessive body weight. A significant proportion of adolescent girls with PCOS is overweight or obese, increased body mass index (BMI) aggravates the clinical symptoms of the disease and increases the risk of metabolic disorders. Visceral fat is a biologically active tissue. It secrets a number of hormones known as adipokines, which contribute significantly to metabolic and endocrine disturbances. The aim of this publication is to summarize the current knowledge on adipokines network, and their influence on symptoms and prognosis of PCOS in adolescent girls. The adipokin network's role in pathogenesis of PCOS and its metabolic complication is presently the field of intensive research, however many results are contradictory. Some adipokines, like leptin, adiponectin, reistin seem to have a direct effect on reproductive system. Leptin affects directly GnRH release, LH secretion and ovarian steroidogenesis. Adiponectin receptors are expressed in the pituitary gland and in the ovary. Visfatin concentration in PCOS girls is increased and positively correlated with androgens level. Opposite relationships were revealed in PCOS referred to omentin-1 concentration. Vaspin level corresponds to the severity of PCOS. Apelin is one of the adipokins, which concentration is increased in adolescents with PCOS and is related to body mass index and insulin resistance. Future studies should focus on revealing the relationships among adipokines in adolescent girls to give the insight into the mechanisms involved in the pathology of PCOS and to identify new therapeutic targets of this syndrome. Pediatr. Endocrinol. 12/2013;4(45):45-54.

Pomiędzy zespołem policystycznych jajników (PCOS) a otyłością istnieje złożona zależność. Większość dziewcząt z PCOS jest otyłych lub ma nadwagę, co nie tylko powoduje nasilenie objawów klinicznych zespołu, ale również prowadzi do powstania zaburzeń metabolicznych. Trzewna tkanka tłuszczowa jest organem biologicznie aktywnym, wydzielającym wiele adipokin, które mogą w sposób znaczący wpływać na powstanie zaburzeń hormonalnych i metabolicznych w PCOS. Celem publikacji jest podsumowanie wiedzy na temat sieci adipokin oraz jej wpływu na 
objawy i przebieg PCOS u dojrzewających dziewcząt. Rola sieci adipokin w patogenezie oraz w powstawaniu metabolicznych zaburzeń w PCOS jest obecnie polem intensywnych badań, a wyniki wielu z nich są sprzeczne. Niektóre $\mathrm{z}$ adipokin, jak leptyna, adiponektyna, rezystyna, wydają się mieć bezpośrednie działanie na system rozrodczy. Leptyna bezpośrednio wpływa na uwalnianie GnRH, sekrecję gonadotropin oraz steroidogenezę jajnikową. Receptory dla adiponektyny są obecne m.in. w przysadce oraz jajniku. Stężenie visfatyny u dziewcząt z PCOS jest podwyższone i koreluje pozytywnie ze stężeniami androgenów. Odwrotną zależność obserwuje się w przypadku omentyny-1. Stężenie vaspiny jest zależne of fenotypu PCOS, natomiast stężenie apeliny, które w PCOS jest podwyższone, jest zależne od indeksu masy ciała i oporności na insulinę. W populacji dziewcząt istnieje szczególna potrzeba dalszych badań, które powinny być ukierunkowane na ujawnienie związków pomiędzy stężeniami adipokin. Ich celem jest zdobycie wiedzy na temat mechanizmów biorących udział w patogenezie PCOS i jego powikłań oraz umożliwienie opracowania nowych opcji terapeutycznych. Endokrynol. Ped. 12/2013;4(45):45-54.

\section{Introduction}

Polycystic ovary syndrome (PCOS) is a heterogeneous disease characterized by hyperandrogenism (HA), ovulation disorders and polycystic ovary morphology. It occurs, depending on the diagnostic criteria, in $6-18 \%$ of the female population of the reproductive age [1]. A significant proportion of women with PCOS is overweight or obese, what not only aggravates the clinical symptoms of the disease, but also increases the risk of metabolic syndrome [1].

The interrelationship between PCOS and excessive body weight is complex. It is well known that fat tissue is not only the main energy reservoir, but also an important endocrine organ. By secreting adipokines, it plays a pivotal role in the regulation of many metabolic processes, such as glucose and lipid metabolism, reproduction and immune response $[2,3]$. It has been shown that obesity can enhance HA, which leads to PCOS development, especially in genetically prone individuals [4]. There is a clear relationship between degree of obesity and symptoms severity in women with PCOS, and even mild reduction in weight leads to significant improvement in menstrual regularity, fertility and hyperandrogenic features. On the other hand, HA and insulin resistance (IR) influence fat accumulation pattern, leading to visceral obesity. As this visceral fat is biologically active, it contributes to further metabolic and endocrine disturbances in PCOS, and creates a kind of vicious circle mechanism [4]. Adipocytokines are the new link between PCOS and obesity, but also IR, lipid disturbances, hypertension, and finally an increased risk of cardiovascular disease.

First symptoms of PCOS can be found already at adolescence and the metabolic disorders may be also present at the second decade of age. Additionally pubertal period is characterized by physiological
IR and hyperinsulinemia. Several studies reported hypeinsulinaemia, increased IR and dyslipidemia in girls with PCOS [5,6]. These metabolic disturbances were more pronounced in obese subjects but they were also present in nonobese girls. The role of adipokines network disturbances at this age could be extremely important for future severity of clinical symptoms of hyperandrogenemia, fertility problems and cardiovascular risk. The aim of this rewiev is to summarize the current knowledge on adipokines network, and their influence on symptoms and prognosis of PCOS in adolescent population (table I).

\section{Leptin}

The discovery of leptin and its role in weight control in rodents, in the last decade of 20 th century, not only aroused hope for effective treatment of human obesity, but also initiated research on the endocrine function of adipose tissue. Leptin is a peptide hormone, produced most abundantly by differentiated adipocytes, but also found in epithelium of digestive tract and trophoblast. It is a mediator of a long-term regulation of energy balance and food intake suppressor, which may be used in replacement therapy for leptin-defficient, morbidly obese patients [7]. Leptin was proposed to be a possible link between energy metabolism and ovarian function [8]. Despite of its metabolic function, it affects directly GnRH release from hypothalamus, LH secretion from the pituitary gland and steroidogenesis in the ovary. [8]. Leptin level in humans varies during menstrual cycle with the peak during the luteal phase [9]. Kisspeptin neurons are a key part of the central pathway by which leptin affects gonadotropin secretion. Leptin increases the plasma concentration of $\mathrm{LH}$ and $\mathrm{FSH}$, as well as $\mathrm{LH}$ pulse frequency and amplitude [10]. Moreover Gregoraszczuk and Rak-Mardyla reported in their in vitro 


\section{Table I}

\begin{tabular}{|c|c|c|}
\hline Adipokines & Serum levels in PCOs adolescent & references \\
\hline \multirow{3}{*}{ Leptin } & Significantly elevated compared to BMI-matched controls & [12] \\
\hline & $\begin{array}{l}\text { Significantly elevated in obese PCOs girls compared to normal weight girls with or } \\
\text { without PCOs }\end{array}$ & [25] \\
\hline & Similar levels compared to BMI-matched controls & {$[13,14]$} \\
\hline \multirow{3}{*}{ Adiponectin } & $\begin{array}{l}\text { Significantly decreased in obese PCOs girls compared to normal weight girls with or } \\
\text { without PCOs }\end{array}$ & [25] \\
\hline & Similar levels between overweight/obese and normal weight PCOs girls & [26] \\
\hline & Significantly decreased compared to BMI-matched controls & [26] \\
\hline Visfatin & Significantly elevated compared to BMI-matched controls & [2] \\
\hline \multirow[b]{2}{*}{ Omentin } & lack of data in girls with PCOS & \\
\hline & Significantly decreased in obese children compared to normal controls & [39] \\
\hline Vaspin & $\begin{array}{l}\text { Insignificantly elevated compared to BMI-matched controls, no correlation between } \\
\text { vaspin and BMI or HOMA-IR }\end{array}$ & [2] \\
\hline \multirow{2}{*}{ Resistin } & Similar levels in obese PCOs girls compared to BMI-matched controls. & [13] \\
\hline & Similar levels compared to BMI-matched controls both fasting and in120' of OGTT & [47] \\
\hline Apelin & $\begin{array}{l}\text { Significantly elevated compared to BMI-matched controls, correlates positively with } \\
\text { BMI and HOMA-IR }\end{array}$ & [2] \\
\hline RBP4 & a statistical trend for higher RBP4 compared with controls & {$[60]$} \\
\hline
\end{tabular}

studies that leptin in elevated doses, via increasing progesterone and testosterone secretions, could be an independent risk factor for cyst formation in the pigs' ovary [11].

There is a growing number of studies concearning leptin in PCOS girls with divergent results and the role of leptin in pathogenesis of PCOS has been not fully clarified yet. Some studies showed higher leptin level in PCOS group compared to BMI matched controls, suggesting that this adipokine can be an additional pathogenic factor of the syndrome [12]. However in most studies, the increase in leptin concentration after adjusting for BMI becomes insignificant $[13,14]$.

It was shown by Kedikova et al that in adolescent girls with PCOS correlation between leptin and BMI, total body adipose tissue, waist circumference and HOMA index is significant [15]. Some studies found also significant positive correlation between leptin and DHEAS, and retinol binding proteine 4 (RBP4), and negative between leptin and SHBG, especially in the group of adolescent girls with HA $[12,16,17]$. An important observation was made by Mahde et al., who noted in PCOS patients the significant difference in leptin level between regular and irregular menstrual cycles [18].

\section{Adiponectin}

Adiponectin is a $30-\mathrm{kDa}$ protein produced in adipocytes, with a complex but well known structure and mechanisms of action. Its receptors are highly expressed in the liver and muscles, but also in the human pituitary gland, where adiponectin, together with resistin, influences LH and FSH release. Moreover it modulates steroidogenesis and directly induces ovarian genes expression via receptors present in granulose and theca cells of ovarian follicles [19]. Besides other actions adiponectin decreases mRNA expression of LH receptor [20]. The main role of adiponectin in other tissues is the sensitization to insulin, as the lower level of this hormone is associated with increased IR [21]. In addition, adiponectin is considered the only anti-atherogenic and anti-inflammatory adipocytokine discovered so far $[21,22]$. It is down-regulated in obesity and its 
circulating concentration increases with dietary restriction and weight loss [21].

It was shown that adiponectin inversely correlates with age and the major determinant of its concentration is total fat mass. Moreover, adiponectin level decreases significantly during puberty. This may be due to an unidentified adaptive physiological mechanism related to normal accrual of body fat in pubertal period [21]. Riestra et al. found that adiponectin levels in adolescent are positively correlated with SHBG and negatively associated with free androgen index (FAI). They suggested that this relationship although being independent of BMI and fat mass can be insulin-dependent [23].

Evidence for the effects of adiponectin on the human ovary was also confirmed by the studies reporting its reduced levels in women diagnosed with PCOS [24]. Cause-effect relationship is less clear, as both, obesity and PCOS, result in hyperandrogenemia. On the other hand adipose tissue synthesis of adiponectin is reduced by androgens, therefore further investigations should be carried out to clarify this correlation.

Some studies showed that adolescent obese girls with PCOS have significantly lower adiponectin levels compared to lean girls with this syndrome, while other revealed that hipoadiponectynemia in teenage girls with PCOS was independent of BMI $[25,26]$. Unlike in adult women with PCOS, lower adiponectin levels in PCOS lean girls, compared with matched controls, are independent of testosterone, fasting glucose and insulin [26]. Therefore it was suggested that PCOS does not play pivotal role in determining adiponectin levels in adolescent girls. This may be due to the fact that teenage girls are at the early stage of PCOS which may not be yet fully developed in all its features.

\section{Visfatin}

Visfatin, first identified in the liver, bone marrow and muscles, was later described in human visceral adipose tissue as an adipokine produced by macrophages [27]. Some studies showed that plasma visfatin correlates significantly with body fat mass, BMI, visceral fat mass and waist-to-hip ratio [28], while in other studies, this relation was much less clear $[29,30]$. However there is no doubt that tissue expression and plasma level of visfatin increase in obesity [31]. Mechanism responsible for the enhanced production of visfatin and resistin in humans might be an increased macrophage population that occurs in obese individuals [27].
Experimental studies revealed the insulin-like activity of visfatin, that could be IR compensatory mechanism [31]. Unfortunately this effect is not strong enough to be effective. Visfatin has been found to promote the expression of interleukins in the endothelial wall, as well as the expression of intercellular adhesion molecule-1, vascular cell adhesion protein-1 and E-selectin [32]. It stimulates proinflammatory activity in a dose-dependent manner, enhancing tumor necrosis factor $\alpha(\mathrm{TNF} \alpha)$ and IL-6 secretion by human monocytes [32]. Therefore the induction of IR by visfatin-related microinflamation seems to outweigh its insulin-mimetic action in obese subjects [33].

The relationship between the plasma concentration of visfatin or the expression of visfatin in visceral adipose tissue and IR in women with PCOS has been reported in several studies. As PCOS is a metabolic disorder associated with IR, compensatory hyperinsulinaemia and hyperglycemia, the expression of this adipokine is therefore higher in adolescents with PCOS than in BMI matched healthy controls [2]. The effect of androgens on the visfatin concentration still remains unclear but it is suggested that visfatin may play a role in the pathogenesis of PCOS [34]. Some authors have shown positive correlation between visfatin and testosterone and FAI [34], while others reported an inverse correlation [29] or even no such a relationship [35]. There are some studies in which no differences between plasma visfatin level in young, obese, and normal weight PCOS and non-PCOS women were observed [34]. This might result from different methods used for determining visfatin level or variability in diagnostic criteria of PCOS.

In the available literature we found only one paper published so far on visfatin level in adolescent girls with PCOS [2]. Cekmez et al reported an increased level of this cytokine in the study group, suggesting its role in early PCOS pathogenesis.

\section{0mentin-1}

Omentin-1 (Omentin, Intelectin-1, Endothelial Lectin HL-1, Intestinal Lactoferrin Receptor) was first found in intestinal Paneth cells. Although it is mainly produced by stromal cells of visceral adipose tissue, it is also found in the human ovaries, placenta, lungs, intestine and heart [36]. In vitro studies have shown that omentin-1 increases insulin signal transduction by stimulating Akt/protein kinase $\mathrm{B}$ phosphorylation, both, in the absence and in 
presence of insulin. It also appears to enhance insulin induced glucose uptake in adipocytes, most likely by glucose transporter 4 (GLUT4) translocation [36]. Several studies showed that omentin-1 levels negatively correlate with BMI, but also with several markers of inflammation, like Il-6, Il-18, TNF $\alpha$, hs-CRP, suggesting that reduced omentin-1 concentration may have an important permissive role in the development of atherogenic process [18]. It was proved in vivo and ex vivo that omentin-1 is down regulated by both glucose and insulin, what can lead to the conclusion that low omentin-1 and high glucose levels have the same causes and consequences [37].

Women with PCOS tend to have lower omentin-1 level when compared to BMI matched controls and the explanation could be a well-known phenomenon of hyperinsulinemia in PCOS women $[18,37,38]$. Other factors that may influence the omentin-1 level are gonadal and adrenal steroids. The significant difference was found in omentin-1 level between the PCOS women with regular and irregular menstrual cycles. It may be due to the fact that omentin- 1 can affect the secretion of hormones regulating ovarian and menstrual function [18]. Negative correlation was found between omentin-1 and androgen level [38]. Elevated androgens concentration in PCOS was proposed to be the one of most influential factors reducing omentin- 1 level in these women.

In obese children serum omentin-1 level is lower than in lean peers and negatively correlated with BMI, waist circumference, HOMA-IR and insulin levels suggesting that omentin-1 might be a biomarker for metabolic dysfunction also in childhood and adolescence [39]. However there are no data about omentin-1 concentration and its role in pathogenesis of PCOS in adolescent girls.

\section{Vaspin}

Visceral adipose tissue-derived serpin (vaspin) is a conserved protein, a member of the serpins' super family (serine proteinase inhibitors). It is present in both subcutaneous and visceral fat depots as well as circulates in serum. Expression of vaspin mRNA in adults is related to parameters of obesity and glucose metabolism, and correlates with adipose tissue abundance. It is considered beneficial because it enhances insulin induction of glucose uptake [40]. It was suggested that increase in vaspin level might represent a compensatory response against the obe- sity. In animal models, administration of recombinant vaspin suppressed the expression of IR-promoting adipokines, including resistin, $\mathrm{TNF} \alpha$ and leptin, and stimulated the synthesis of insulin-sensitizing adipokine - adiponectin and GLUT4 [40]. These findings support the hypothesis that vaspin down-regulates the expression of genes associated with IR and that this action is more prominent in the abdominal fat [40].

Significantly higher serum vaspin level was found in patients with PCOS when compared to healthy controls [41]. Some studies reported positive associations of vaspin concentration in adipose tissue with parameters of obesity and IR [41]. Koiou et al. compared vaspin concentration among different PCOS phenotypes. They noticed its higher level in PCOS women with anovulatory cycles and hyperandrogenemia than in PCOS ovulatory women with hyperandrogenemia or PCOS anovulatory women with normal androgen levels [41]. Vaspin level corresponds to the severity of PCOS and is significantly increased in its 'classical' phenotype [41]. However, other studies involving vaspin have not found significant relationships [2].

Cekmez et al. found higher levels of vaspin in adolescents with PCOS, but the difference between PCOS group and controls was not statistically significant [2]. Moreover, there was also no correlation between vaspin concentration and BMI or HOMA-IR. In another study Akbarzadeh et al. showed that PCOS is not a determinant of decreased vaspin plasma level [42].

\section{Resistin}

Resistin is a cysteine-rich peptide expressed mainly in macrophages and preadipocytes of visceral adipose tissue. Its level is associated with metabolic impairment and IR. It has been suggested that resistin can be involved in pathogenesis of cardiovascular diseases, however the data are inconsistent. On the other hand it is well known that this adipokine increases secretion of TNF- $\alpha$ and IL- 6 and therefore is considered a pro-inflammatory molecule [43].

Contradictory results have been reported in humans with regard to the connections of resistin with BMI, IR and PCOS. Some studies found BMI to be the main factor determining serum resistin concentration both in healthy subjects and patients with PCOS $[13,44]$. In contrast, other studies did not find such association [45]. Chinese researchers de- 
scribed positive resistin correlation with HOMA-IR, LH and LH/FSH ratio; they also noticed higher level of resistin in PCOS groups in comparison with BMI matched controls [46]. However, there are many studies that showed no difference in resistin levels between PCOS patients and healthy controls. Also no variation in resistin gene promoter was found to be associated with PCOS [13, 19, 45, 47]. The role of this adipokine in pathogenesis of PCOS still remains uncertain and needs further studies.

Although resistin was found to be higher in PCOS with irregular than regular menstrual cycles, studies were unable to show any correlation between androgen and resistin levels except for the correlation between free testosterone and resistin found by Bideci et al [13, 45]. Moreover, it was shown that in cultured human theca cells, resistin enhanced $17 \alpha$-hydroxylase activity, a marker of ovarian HA in PCOS women [48]. This correlation was not confirmed by $\mathrm{Lu}$ et al who studied resistin and sex steroids levels in the serum and follicular fluid [45]. Their results suggest that resistin does not play a pivotal role in regulation of steroidogenesis, maturation, and development of oocytes, but it may have a local paracrine action in the regulation of IR in obesity and PCOS.

Ortega et al. observed that resistin levels are related to fat mass, but not to BMI in children and adolescents [49]. In adolescent girls with PCOS resistin concentration was not related to any IR indices [47]. However, significant correlations between resistin level and SHBG and free testosterone were found suggesting that this adipokin could be the risk factor for low SHBG at least during puberty [13].

\section{Apelin}

Apelin is a peptide that was designated as an endogenous receptor ligand and is found in several organs like heart, brain, kidneys, lungs and mammary glands. Widespread expression of apelin in peripheral tissues is associated with its synthesis by endothelial cells and cardiovascular system appears to be a main source of it [50].

Firstly apelin has been shown to be involved in the regulation of cardiovascular function, fluid homeostasis, vessel formation and cell proliferation. It was proved that exogenous apelin lowers blood pressure via a nitric oxide-dependent mechanism [50]. Apelin synthesis in adipocytes is stimulated by insulin, and its plasma level markedly increases in obesity, and is associated with IR and hyperinsu- linemia $[2,51]$. This cytokine exerts glucose lowering effect caused by enhanced glucose utilization in skeletal muscle and adipose tissue [52]. Some authors suppose that overproduction of apelin in the obese subjects could be one of the protective mechanisms against obesity-related complications [53].

There are only few studies describing apelin in PCOS patients and only one relates to youth [2]. Choi et al. noticed that serum apelin levels were significantly lower in PCOS group than in the controls. There was no difference between PCOS patients with and without HA, however there was a negative correlation between apelin and total testosterone and FAI [54]. The study by Olszanecka-Glinianowicz et al. [55] showed that the concentrations of apelin-36 and -12 were similar in PCOS and non-PCOS groups. However, the separate analysis of obese PCOS and non-PCOS subgroups revealed significantly lower plasma level of this adipokine in the PCOS group. There was also a negative correlation between serum insulin concentration, HOMA-IR value, $\mathrm{LH}$ or $\mathrm{LH} / \mathrm{FSH}$ ratio and plasma apelin level. Moreover, in the same study apelin concentration correlated positively with adiponectin and inversely with leptin and resistin level. Cekmez et al. published completely different results, as serum apelin level was significantly higher in adolescent girls with PCOS than in healthy controls, and it correlated positively with BMI and HOMA-IR [2].

\section{Retinol Binding Protein 4}

RBP4 is a carrier for vitamin A in the blood. Hepatocytes are considered the main source of circulating RBP4, but adipose tissue has the second highest expression level. RBP4 appears to impair insulin signaling in muscles, inhibits glucose uptake by GLUT4 suppression in adipose tissue, and interferes with insulin-mediated suppression of glucose production in the liver [56]. Furthermore, increased serum RBP4 level is known to stimulate hepatic gluconeogenesis. Hypertriglyceridemia, accompanied by hyperinsulinemia, may trigger RBP4 synthesis and secretion in the liver or ectopic fat and RBP4 has been found to be closely related to the liver fat [56]. Data on the relationship between RBP4 level and various markers of obesity are inconsistent, which may indicate that RBP4 level is correlated with some but not all parameters of adiposity. Several investigators demonstrated that elevated serum RBP4 concentration is associated with increased BMI, waist-hip ratio, waist circum- 
ference, total cholesterol, and serum triglycerides levels $[29,57,58]$. In contrast, other studies did not find any correlation between RBP4 level and BMI and cholesterol concentration $[16,57]$.

In the study on Asian population, Weiping et al. proved that serum RBP4 level was significantly increased in PCOS women, both lean and overweight/ obese group, and it was significantly associated with insulin sensitivity [57]. Whereas Polish study revealed significantly higher RBP4 levels in normal weight PCOS than in normal weight control as well as in obese PCOS. In the obese PCOS women and in the normal weight non-PCOS women lower RBP4 levels than in the obese non-PCOS subgroup were observed. As higher IR in obese PCOS than nonPCOS subgroups was found [29], these results indicate that RBP4 may be a contributing factor linking adipose tissue with IR in PCOS. On the other hand, some investigators did not find a correlation between RBP4 level and IR and no difference in RBP4 levels between PCOS and controls matched for BMI [58].

Different levels of RBP4 were found also across the spectrum of PCOS manifestations [16, 29]. It was suggested that RBP4 might be linked, not only to the metabolic, but also to the hormonal features. Some investigators did not reveal any association between RBP4 level and gonadotropins, estradiol, and androgens concentration [16, 57]. Also oral contraceptive pill was shown not to influence RBP4 level [58]. Contrary to these results, some studies showed a positive correlation between circulating RBP4 level and plasma LH concentration and LH/FSH ratio, raising a question of whether or not RBP4 directly modulates pituitary hormone release [29]. Tan et al. demonstrated that 17-OH-estradiol is capable of inducing adipose tissue RBP4 biosynthesis and secretion [59]. In adolescent with PCOS
Sopher et al. found a statistical trend for higher RBP4. In this study RBP4 concentration correlated with body fat, triglycerides, IR and androgens level, however this last relationship was strongly related to the body fat. Authors suggested that RBP4 could be involved in dyslipidemia associated with PCOS [60].

\section{Conclusions}

PCOS is the disorder which is highly associated with obesity, thus adipokines network may play a crucial role, not only in metabolic disturbances, but also in hormonal disorders present in this syndrome. The studies investigating adipocytokines in PCOS are usually carried out in the adults. There are many discrepancies in their results, which may be explained by cohort size, selection bias, geographical divergence within the patients with PCOS, stage of menstrual cycle, or methodological differences in measurements. Nevertheless strong associations between adipokines and various PCOS phenotypes point to complex network of interactions and its roles in pathophysiology of PCOS. Future studies should focus on revealing the relationships among adipokines, especially in adolescent population. $\mathrm{Pu}-$ bertal period is associated with increased IR, that could be connected with shifting of adipokines toward those related to reduced insulin action. Higher visfatin and apelin, together with lower adiponectin found in adolescent with PCOS can support the idea that the high levels of adipocytokines related to IR, may play a role in the early development of PCOS in obese adolescents [2]. Future studies should focus on revealing the relationships among adipokines, particularly in adolescent population, to give the insight into the pathology of PCOS and to identify new therapeutic targets of this syndrome. 


\section{PIŚMIENNICTWOIREFERENCES}

[1] Lim S.S., Norman R.J., Davies M.J. et al.: The effect of obesity on polycystic ovary syndrome: a systematic review and meta-analysis. Obes. Rev., 2013:14, 95-109.

[2] Cekmez F., Cekmez Y., Pirgon 0. et al.: Evaluation of new adipocytokines and insulin resistance in adolescents with polycystic ovary syndrome. Eur. Cytokine. Netw., 2011:22, 32-37.

[3] Fulghesu A.M., Sanna F., Uda S. et al.: IL-6 serum levels and production is related to an altered immune response in polycystic ovary syndrome girls with insulin resistance. Mediators Inflamm., 2011:2011, 389317.

[4] Reinehr T., de Sousa G., Roth C.L. et al.: Androgens before and after weight loss in obese children. J. Clin. Endocrinol. Metab., 2005:90, 5588-95.

[5] Arslanian S.A., Witchel S.F.: Polycystic ovary syndrome in adolescents: is there an epidemic? Endocrinol. Diabetes., 2002:9, 32-42.

[6] Ibanez L., Potau N., De Zegher F.: Endocrinology and metabolism after premature pubarche in girls. Acta. Paediatr. Suppl., 1999:433, 73-77.

[7] Licinio J., Caglayan S., Ozata M. et al.: Phenotypic effects of leptin replacement on morbid obesity, diabetes mellitus, hypogonadism, and behavior in leptin-deficient adults. Proc. Natl. Acad. Sci. USA, 2004:101, 4531-4536.

[8] Kale-Gurbuz T., Akhan S.E., Bastu E. et al.: Adiponectin, leptin and ghrelin levels in obese adolescent girls with polycystic ovary syndrome. J. Pediatr. Adolesc. Gynecol., 2013:26, 27-30.

[9] Hausman G.J., Barb C.R., Lents C.A.: Leptin and reproductive function. Biochimie. 2012:94, 2075-81.

[10] González R.R., Simón C., Caballero-Campo P. et al.: Leptin and reproduction. Hum. Reprod. Update., 2000:6, 290-300.

[11] Gregoraszczuk E.K., Rak-Mardyła A.: Supraphysiological leptin levels shift the profile of steroidogenesis in porcine ovarian follicles toward progesterone and testosterone secretion through increased expressions of CYP11A1 and 17b-HSD: a tissue culture approach. Reproduction, 2013:145, 311-7.

[12] Zukauskaite S., Seibokaite A., Lasas L. et al.: Serum hormone levels and anthropometric characteristics in girls with hyperandrogenism. Medicina (Kaunas), 2005:41, 305-12.

[13] Bideci A., Camurdan M.O., Yeşilkaya E. et al.: Serum ghrelin, leptin and resistin levels in adolescent girls with polycystic ovary syndrome. J. Obstet. Gynaecol. Res., 2008:34, 578-84.

[14] Veldhuis J.D., Pincus S.M., Garcia-Rudaz M.C. et al.: Disruption of the synchronous secretion of leptin, LH, and ovarian androgens in nonobese adolescents with the polycystic ovarian syndrome. J. Clin. Endocrinol. Metab., 2001:86, 3772-8.

[15] Kedikova S.E., Sirakov M.M., Boyadzhieva M.V.: Leptin levels and adipose tissue percentage in adolescents with polycystic ovary syndrome. Gynecol Endocrinol, 2013:29, 384-7.

[16] Yildizhan R., Ihan G.A., Yildizhan B. et al.: Serum retinol-binding protein 4, leptin, and plasma asymmetric dimethylarginine levels in obese and nonobese young women with polycystic ovary syndrome. Fertil Steril, 2011:96, 246-50.

[17] Pehlivanov B., Mitkov M.: Serum leptin levels correlate with clinical and biochemical indices of insulin resistance in women with polycystic ovary syndrome. Eur. J. Contracept Reprod. Health Care, 2009:14, 153-9.

[18] Mahde A., Shaker M., Al-Mashhadani Z.: Study of Omentin1 and Other Adipokines and Hormones in PCOS Patients. Oman. Med. J., 2009:24, 108-18.

[19] Olszanecka-Glinianowicz M., Kuglin D., Dabkowska-Huc ' A. et al.: Serum adiponectin and resistin in relation to insulin resistance and markers of hyperandrogenism in lean and obese women with polycystic ovary syndrome. Eur. J. Obstet. Gynecol. Reprod. Biol., 2011:154, 51-6.

[20] Maliqueo M., Galgani J.E., Pérez-Bravo F., Echiburú et al.: Relationship of serum adipocyte-derived proteins with insulin sensitivity and reproductive features in pre-pubertal and pubertal daughters of polycystic ovary syndrome women. Eur. J. Obstet. Gynecol. Reprod. Biol., 2012:161, 56-61.

[21] Weyer C., Funahashi T., Tanaka S. et al.: Hypoadiponectinemia in obesity and type 2 diabetes: close association with insulin resistance and hyperinsulinemia. J. Clin. Endocrinol. Metab., 2001:86, E1930-5.

[22] Arikan S., Bahceci M., Tuzcu A. et al.: Serum resistin and adiponectin levels in young non-obese women with polycystic ovary syndrome Gynecol. Endocrinol, 2010:26, 161-166.

[23] Riestra P., Garcia-Anguita A., Ortega L. et al.: Relationship of adiponectin with sex hormone levels in adolescents. Horm. Res. Paediatr., 2013:79, 83-7.

[24] Toulis K.A., Goulis D.G., Farmakiotis D. et al.: Adiponectin levels in women with polycystic ovary syndrome: a systematic review and a meta-analysis. Hum. Reprod. Update., 2009:15, 297-307.

[25] Pinhas Hamiel 0., Singer S., Pilpel N. et al.: Adiponectin levels in adolescent girls with polycystic ovary syndrome (PCOS). Clin. Endocrinol. (0xf), 2009:71, 823-7.

[26] Yasar L., Ekin M., Gedikbasi A. et al.: Serum adiponectin levels in high school girls with polycystic ovary syndrome and hyperandrogenism. J. Pediatr. Adolesc. Gynecol., 2011:24, 90-3.

[27] Curat C.A., Wegner V., Sengenes C. et al.: Macrophages in human visceral adipose tissue: increased accumulation in obesity and a source of resistin and visfatin. Diabetologia, 2006:49, 744-747. 
[28] Zahorska-Markiewicz B., Olszanecka-Glinianowicz M., Janowska J. et al.: Serum concentration of visfatin in obese women. Metabolism, 2007:56, 1131-4.

[29] Olszanecka-Glinianowicz M., Madej P., Zdun D. et al.: Are plasma levels of visfatin and retinol-binding protein 4 (RBP4) associated with body mass, metabolic and hormonal disturbances in women with polycystic ovary syndrome? Eur. J. Obstet. Gynecol. Reprod. Biol., 2012:162, 55-61.

[30] Seow K.M., Hwang J.L., Wang P.H. et al.: Expression of visfatin mRNA in peripheral blood mononuclear cells is not correlated with visfatin mRNA in omental adipose tissue in women with polycystic ovary syndrome. Hum. Reprod., 2011:26, 2869-73.

[31] Ziora K., Oswiecimska J., Swietochowska E. et al.: Assessement of serum visfatin levels in girls with anorexia nervosa. Clin. Endocrinol., 2012:76, 514-519.

[32] Moschen A.R., Kaser A., Enrich B. et al.: Visfatin, an adipocytokine with proinflammatory and immunomodulating properties. J. Immunol., 2007:178, 1748-58.

[33] Olszanecka-Glinianowicz M., Kocełak P., Janowska J. et al.: Plasma visfatin and tumor necrosis factor-alpha (TNF-a) levels in metabolic syndrome. Pol. Heart. J., 2011:69, 802-7.

[34] Kowalska I., Straczkowski M., Nikolajuk A. et al.: Serum visfatin in relation to insulin resistance and markers of hyperandrogenism in lean and obese women with polycystic ovary syndrome. Hum. Reprod., 2007:22, 1824-9.

[35] Chan T.F., Chen Y.L., Chen H.H. et al.: Increased plasma visfatin concentrations in women with polycystic ovary syndrome. Fertil. Steril., 2007:88, 401-5.

[36] Yang R.Z., Lee M.J., Hu H. et al.: Identification of omentin as a novel depot-specific adipokine in human adipose tissue: Possible role in modulating insulin action. Am. J. Phys. Endocrinol. Metab., 2006:290, 1253-1261.

[37] Tan B.K., Adya R., Farhatullah S. et al.: Omentin-1, a novel adipokine, is decreased in Overweight insulin resistant women with the polycystic ovary syndrome: Ex vivo and in vivo Regulation of Omentin-1 by Insulin and Glucose; Diabetes, 2008:57, 801-808.

[38] Choi J.H., Rhee E.J., Kim K.H. et al.: Plasma omentin-1 levels are reduced in non-obese women with normal glucose tolerance and polycystic ovary syndrome. Eur. J. Endocrinol., 2011:165, 789-96.

[39] Catli G., Anik A., Abaci A. et al.: Low Omentin-1 Levels Are Related with Clinical and Metabolic Parameters in Obese Children. Exp. Clin. Endocrinol. Diabetes., 2013 Oct 1. [Epub ahead of print] PubMed PMID: 24085389.

[40] Hida K., Wada J., Eguchi J. et al.: Visceral adipose tissue-derived serine protease inhibitor: a unique insulinsensitizing adipocytokine in obesity. Proc. Natl. Acad. Sci. USA, 2005:102, 10610-10615.

[41] Koiou E., Dinas K., Tziomalos K. et al.: The phenotypes of polycystic ovary syndrome defined by the 1990 diagnostic criteria are associated with higher serum vaspin levels than the phenotypes introduced by the 2003 criteria. Obes. Facts., 2011:4, 145-50.

[42] Akbarzadeh S., Ghasemi S., Kalantarhormozi M. et al.: Relationship among plasma adipokines, insulin and androgens level as well as biochemical glycemic and lipidemic markers with incidence of PCOS in women with normal BMI. Gynecol Endocrinol., 2012:28, $521-4$.

[43] Choi S.H., Hong E.S., Lim S.: Clinical implications of adipocytokines and newly emerging metabolic factors with relation to insulin resistance and cardiovascular health. Front Endocrinol (Lausanne), 2013:4, 97.

[44] Ziora K., Oswiecimska J., Swietochowska E. et al.: Assessment of serum levels resistin in girls with anorexia nervosa. Neuroendocrinol Lett, 2011:32, 101-106.

[45] Lu X.E., Huang H.F., Li M.G., Zhu et al.: Resistin levels of serum and follicular fluid in non-obese patients with polycystic ovary syndrome during IVF cycles. J. Zhejiang. Univ. Sci. B., 2005:6, 897-902.

[46] Wang Y., Xie X., Zhu W.J.: Huazhong Serum adiponectin and resistin levels in patients with polycystic ovarian syndrome and their clinical implications. Univ. Sci. Technolog. Med. Sci., 2010:30, 638-42.

[47] Güven A., Ozgen T., Aliyazicioğlu Y.: Adiponectin and resistin concentrations after glucose load in adolescents with polycystic ovary syndrome. Gynecol Endocrinol., 2010:26, 30-8.

[48] Xita N., Georgiou I., Tsatsoulis A. et al.: A polymorphism in the resistin gene promoter is associated with body mass index in women with polycystic ovary syndrome. Fertil. Steril., 2004:82, 1466-1467.

[49] Ortega L., Riestra P., Navarro P. et al.: Resistin levels are related to fat mass, but not to body mass index in children. Peptides., 2013:49C, 49-52.

[50] Ricardo L., João F., Adelino F.: The apelinergic system: the role played in human physiology and pathology and potential therapeutic applications. Arq. Bras. Cardiol., 2008:90, 343-9.

[51] Boucher J., Masri B., Daviaud D. et al.: Apelin, a newly identified adipokine up-regulated by insulin and obesity. Endocrinology, 2005:146, 1764-71.

[52] Dray C., Knauf C., Daviaud D. et al.: Apelin stimulates glucose utilization in normal and obese insulin-resistant mice. Cell. Metab., 2008:8, 437-45.

[53] Castan-Laurell I., Boucher J., Dray C. et al.: Apelin, a novel adipokine over-produced in obesity: friend or foe? Mol. Cell. Endocrinol., 2005:245, 7-9.

[54] Choi Y.S., Yang H.I., Cho S., Jung et al.: Serum asymmetric dimethylarginine, apelin, and tumor necrosis factor- $\alpha$ levels in nonobese women with polycystic ovary syndrome. Steroids., 2012:77, 1352-8. 
[55] Olszanecka-Glinianowicz M., Madej P., Nylec M. et al.: Circulating apelin level in relation to nutritional status in polycystic ovary syndrome and its association with metabolic and hormonal disturbances. Clin. Endocrinol. (0xf), 2013:79, 238-42.

[56] Yang Q., Graham T.E., Mody N. et al.: Serum retinol binding protein 4 contributes to insulin resistance in obesity and type 2 diabetes. Nature, 2005:436, 356-62.

[57] Weiping L., Qingfeng C., Shikun M. et al.: Elevated serum RBP4 is associated with insulin resistance in women with polycystic ovary syndrome. Endocrine., 2006:30, 283-7.

[58] Hutchison S.K., Harrison C., Stepto N. et al.: Retinol-binding protein4 and insulin resistance in polycystic ovary syndrome. Diabetes. Care., 2008:31, 1427-32.

[59] Tan B.K., Chen J., Lehnert H. et al.: Raised serum, adipocyte, and adipose tissue retinol-binding protein 4 in overweight women with polycystic ovary syndrome: effects of gonadal and adrenal steroids. J. Clin. Endocrinol. Metab., 2007:92, 2764-72.

[60] Sopher A.B., Gerken A.T., Blaner W.S. et al.: Metabolic manifestations of polycystic ovary syndrome in nonobese adolescents: retinol-binding protein 4 and ectopic fat deposition. Fertil Steril., 2012:97, 1009-15. 